UDC 372.881 .111 .1

DOI: $10.24144 / 2524-0609.2019 .45 .159-163$

\author{
Skril Iryna \\ Senior Lecturer \\ Head of Department of Foreign Languages \\ Lviv Professional College of Hospitality, Tourism and Restaurant Service \\ Lviv, Ukraine \\ iryna.skril@gmail.com \\ ORCID ID: http://orcid.org/0000-0002-5252-0521
}

\title{
SIMULATIONS IN FORMING ENGLISH LEXICAL COMPETENCE IN DIALOGIC SPEAKING FOR PROSPECTIVE EXPERTS OF HOSPITALITY AND RESTAURANT SERVICE
}

\begin{abstract}
The purpose of the article is to analyse the simulations in forming English lexical competence in dialogic speaking for prospective experts of hospitality and restaurant service. The structure, forms and samples of simulations will be shown in the article. Methods of research used: analysis and synthesis, induction and deduction and review of pedagogical scientific sources of literature in order to find out the theoretical foundations and state of development of the problem under study. The article deals with the simulations in forming English lexical competence in dialogic speaking for prospective experts of hospitality and restaurant service. Simulation is specified as one of the interactive methods. The structure of a simulation is analysed. Simulation is defined as the way of reproducing real-life situations in English in the artificially created conditions. The technique of simulations is becoming the first choice for ESP teachers due to the fact that this technique is considered the backbone of an environment which gives learners the opportunity to use language in a creative and communicative way. Integrating simulations in language classes engages the learners in first-hand experiences of knowledge. This knowledge, in turn, bridges the gap between the classroom world and the real-life experiences that students encounter. The most common view of simulations is that they provide a way of creating a rich communicative environment (a representation of reality) where students actively become a part of some real-world system and function according to predetermined roles as members of that group. In short, by using simulation, the students will get more chances to practice their English grammatically and pragmatically, because it makes them in a real world. In a simulation students are given a task to perform or problem to solve together with the necessary background information and environment in which to do it. Simulations provide a realistic setting for more extensive interaction in which students can get more personally involved.
\end{abstract}

Key words: simulation; dialogic speaking; lexical competence; role play.

Introduction.Today hospitality industry is one of the highly profitable branches of economy, which in the current conditions of globalization is developing continuously and dynamically. It is true that the hospitality industry includes a variety of career opportunities for progression and promotion. But, most of the times they are out of reach unless a person who is pursuing them is a proficient and a confident user of the English language. It is more than just important to effectively communicate in English, no matter where in the world you live, travel or work. Certainly speaking fluently in a language is imperative when working in an English speaking nation.

The current state of international relations of Ukraine, its output into European and world community, makes it necessary to consider a foreign language as an important means of intercultural communication. There are many techniques can be applied in teaching English for prospective experts of hospitality and restaurant service, one of them is simulation. The most common view of simulations is that they provide a way of creating a rich communicative environment (a representation of reality) where students actively become a part of some realworld system and function according to predetermined roles as members of the group.

The analysis of scientific studies has shown that the simulations in forming English lexical competence in dialogic speaking for prospective experts of hospitality and restaurant service arouse a constant interest in the field of foreign language education. Most researchers attribute the formation of communicative competence with the formation of professional competence (O.Bihych, I.Bim, V.Buhbinder, I.Zadorozhna, O.Kvasova, L.Morska, N.Mykytenko, N.Minina, S.Nikolaieva, Ye.Passov, I.Simkova, I.Semeriak, D.Tereschuk). The works dedicated to the technologies of teaching foreign language have been analyzed by scholars such as I.Bim,
R.Milrood, E.Polat, G.Neuner, J.Richards, W.Rivers, E.Rogers, M.West and others. The use of simulations in teaching English for specific purpose has been studied by I.Semeriak, O.Tarnopolskyi, D.Tereschuk, O.Torichnyi, O.Shcherbak. However, in theory and practice the simulations in forming English lexical competence in dialogic speaking for prospective experts of hospitality and restaurant service are not fully investigated.

The purpose of the article is to analyse the simulations in forming English lexical competence in dialogic speaking for prospective experts of hospitality and restaurant service. The structure, forms and samples of simulations will be shown in the article. Methodology of the Research. The communicative approach is based on the idea that learning language successfully comes through having to communicate real meaning. When learners are involved in real communication, their natural strategies for language acquisition will be used, and this will allow them to learn to use the language. Methods of research are used such as analysis and synthesis, induction and deduction and review of pedagogical scientific sources of literature in order to find out the theoretical foundations and state of development of the problem under study.

Results and Discussion. In an increasingly globalised world, social interactions in hospitality are becoming increasingly multicultural. Strong language skills are imperative for global hospitality companies serving international customers. Employees with poor language skills can lead to mixed customer experience, poor ratings and lost sales. Briefing everyone about the many advantages of English language is notable to understand that communication skills are a crucial element of hospitality industry. Sidewise, it is also important to understand the performance expectations since it is a key to any achievement in tourist satisfaction. Good oral and 
written communication skills are the top requirement in the hospitality industry.

Another important fact about the hospitality program is that a hospitality program will itself encourage critical thinking, tourist problem solving etc. whenever necessary. Communicative competence refers to a learner's ability to use language to communicate successfully. When in the tourism industry, supply and demand side must communicate perfectly in order to meet the quality standards.

The goal of teaching speaking skills is communicative efficiency. Learners should be able to make themselves understood, using their current proficiency to the fullest. They should try to avoid confusion in the message due to faulty pronunciation, grammar, or vocabulary, and to observe the social and cultural rules that apply in each communication situation.

Dialogic communication is an interaction where each person involved plays the role of both speaker and listener. In other words, this is a communication where everyone has a chance to express themselves. Mutual understanding and empathy are hallmarks of dialogic communication. There is a deep concern and respect for the other person and the relationship between them in this type of communication.

In this type of interaction, the listeners and speakers have the right to make their own choices without coercion, pressure, fear or threat of punishment. Dialogic communicators avoid negative criticism and negative personal judgment and use positive criticism in their stead. The communicators always show a willingness to listen to each other and indicate involvement by giving cues such as nonverbal actions, paraphrasing, expressions of agreements, etc. Dialogic communicator also does not manipulate the conversation to achieve his or her goals (Johannesen, 1996).

Simulations are instructional scenarios where the learner is placed in a «world» defined by the teacher. They represent a reality within which students interact. The teacher controls the parameters of this «world» and uses it to achieve the desired instructional results. Students experience the reality of the scenario and gather meaning from it.

A simulation includes time for reflection and processing which allows students to share their experiences, assess their learning and evaluate their assessments against the intended outcomes of the simulation. In addition to accomplishing the objectives of the simulation activity, students often become interested in the real world system on which it is based and what makes it work the way it does (Chilcott, 1996).

A simulation is a form of experiential learning. It is a strategy that fits well with the principles of StudentCentred and constructivist learning and teaching. Simulations take a number of forms. They may contain elements of: a game, a role-play, or an activity that acts as a metaphor. Simulations are characterised by their nonlinear nature and by then controlled ambiguity within which students must make decisions. The inventiveness and commitment of the participants usually determines the success of a simulation.

Simulations promote the use of critical and evaluative thinking. Because they are ambiguous or open-ended, they encourage students to contemplate the implications of a scenario. The situation feels real and thus leads to more engaging interaction by learners. Simulations promote concept attainment through experiential practice. They help students understand the nuances of a concept. Students often find them more deeply engaging than other activities, as they experience the activity first-hand, rather than hearing about it or seeing it. Simulations help students appreciate more deeply the management of the environment, politics, community and culture. For example, by participating in a resource distribution activity, students might gain an understanding of inequity in society. Simulations can reinforce other skills indirectly, such as debating, a method associated with some large-scale simulations, and research skills.

According to G.Sturtridge the structure of a simulation makes it attractive to the materials designer and teacher, as it allows for the integration of different types of learning materials and the practice of different skills (Sturtridge, 1977):

Informational input
The task
The aim
The roles
Background

Phase I

Phase II
Group work
Discussion of the task or problem
Phase III
Feedback
Assessment of students' performance
Discussion of mistakes

\author{
Linguistic input \\ Text \\ Exercises \\ Discussion strategies
}

A distinction is sometimes made between simulation and role-play. A simulation is a highly developed roleplay, almost a miniplay, that it is not scripted. The teacher sets up a simulated environment, such as the traffic accident set-up described earlier. The key in to structure the roles and action around a problem or series of problems.

A simulation is more involved than a single transactional episode, such as a customer returning a defective vacuum cleaner or making an appointment. In simulations, students may have to perform a variety of speeches and activities. For example, a simulation of staying in a hotel could involve setting up a room, a receptionist's desk, and a restaurant. Students check in with the receptionist, spend time in the living area, and are called one-by-one to see the receptionistr who proceeds with facilities. We can even extend our simulations to include a "trip" to the pharmacy to fill a prescription. The role-play, by contrast, might be just the conversation between the receptionist and the guest. There are a number of sources of simulation games and activities. T. Genzel and J. Cummings describe a shopping simulation (Genzel, Cummings, 1986) and H. Curtain and C. Pesola describe fantasy simulations (Curtain, Pesola, 1988). Such simulations can create a vivid connection between the classroom experience and the target culture.

Resources and time are required to develop a quality learning experience with simulations. Assessment 
of student learning through simulation is often more complex than with other methods. Simulated experiences are more realistic than some other techniques and they can be so engaging and absorbing that students forget the educational purpose of the exercise.

Simulations can be used in the classroom to cover a wide range of topics and functions. Since the objective of language learners vary, simulations, in turn, vary. Not every simulation can be applied at any proficiency level; this is why teachers shall differentiate between the types of simulations suitable and applicable for each level (Fanous).

The teacher can implement situations that any person can face in real life such as being a waiter who has to give the recommendations to a guest, being a graduate who has to go through a job interview, being an employee that has to take a certain decision at a hotel, and others.

For such kind of real-life simulations, the teachers can set the simulation in the form of a scenario, which clearly explains the situation the students are facing, their roles, tasks, the way they are expected to behave throughout the simulation and the output that they shall come up with at its end. According to Jones the controller should provide enough information for the participants to understand what is involved in the briefing stage and ensure that all required documents are present (Jones, 2002). It is worth noting that teacher shall stress on the importance of each role, and the importance of accepting it, in addition to the fact that learners shall not play or act, but shall behave as per their role in the simulation. Here are some examples:

I. You are a waiter. A customer comes to your restaurant and wants to organize a banquette. You are discussing sitting arrangements.

- Name all the possible sitting arrangements.

- Ask the customer about the number of people

- Ask what the preferences of the customer are

- Suggest the most appropriate variant.

You are a customer in the restaurant. You want to organize a banquette. You are discussing sitting arrangements.

- Tell the reason of celebration

- Tell the number of people

- Say what suggestion you like most

II. You are a waiter in a restaurant. A couple of young people wants to organize their wedding reception there. You have to discuss the best menu.

- Ask what are their preferences

- Ask all the necessary information

- Suggest the most popular dishes in your restaurant

You are customers of a restaurant. You want to organize your wedding reception in the restaurant. You want to discuss your menu.

- Tell what you would like to see first of all

- Inform the waiter about the number of guests, whether there will be more young or older people, etc.

- Take into consideration the waiter's recommendations.

III. You are the waiter in a restaurant. You show the customers to a spare table. They tell you that they want to sit at a window.

- Apologize

- Tell them that as they can see all the tables at the window are already taken

- Explain that the table they point to isn `t free as it has been already reserved

- Suggest another table which is not at the window.

You come to a restaurant. The waiter shows you to a table.

- Tell him that you want to sit at the window
- Point to the table at the window where there are no people

- Apologize and agree to sit at another table.

Throughout the simulation, the teacher takes the role of an observer only. He/she can move around taking notes about learners' error and weaknesses to be shared with them in the debriefing stage. As an assessment, learners can write an essay describing their experience in the origami company in terms of group work and cooperation, autonomous learning, and the reflection on the simulation as a whole. During the debriefing part, the teacher can point out the points of strength and weakness each learner had. In other words, the teacher can comment on the verbal and non-verbal skills in terms of language use and communication aside to group work and interaction (Fanous, 2019).

If simulation has an element of competition, it is important to remind the students that the goal is not to win, but to acquire knowledge and understanding.

In a simulation, guided by a set of parameters, students undertake to solve problems, adapt to issues arising from their scenario and gain an awareness of the unique circumstances that exist within the confines of the simulation.

Some simulations require one hour, while others may extend over weeks. Scope and content varies greatly. However, similar principles apply to all simulations.

1) Prepare in advance as much as possible

- Ensure that students understand the procedures before beginning. Frustration can arise when too many uncertainties exist. Develop a student guide and put the rules in writing.

- Try to anticipate questions before they are asked. Some simulations are fast-paced, and the sense of reality is best maintained with ready responses.

- Know what you want to accomplish. Many simulations have more than one instructional goal. Developing evaluation criteria, and ensure that students are aware of the specific outcomes expected of them in advance.

2) Monitor the process closely

Teachers must monitor the simulation process to ensure that students both understand the process and benefit from it. Ask yourself:

- Does this simulation offer an appropriate measure of realism for my group of students?

- Are the desired instructional outcomes well defined?

- Is the level of ambiguity manageable for this group?

- Does the student demonstrate an understanding of his/her role?

- Are problem-solving techniques in evidence?

- Does the research being generated match the nature of the problem?

- Is cooperation between participants in evidence?

- Has the student been able to resolve the issue satisfactorily?

- Does the student provide meaningful answers to probing questions?

- Will follow-up activities be necessary?

3) Consider what to assess

We might find it best to use simulations as part of the process of learning rather than as a summative measure of it. We can use follow-up activities to establish a measure of comprehension and as a de-briefing mechanism when students return to reality (e.g. use reflection on the process as the assessable component of the activity, rather than participation in the simulation itself).

Conclusions. The most common view of simulations is that they provide a way of creating a rich communicative environment (a representation of reality) where students actively become a part of some real-world 
system and function according to predetermined roles as members of that group. In short, by using simulation, the students will get more chances to practice their English grammatically and pragmatically, because it makes them in a real world. In a simulation students are given a task to perform or problem to solve together with the necessary background information and environment in which to do it. Simulations provide a realistic setting for more extensive interaction in which students can get more personally involved.

\title{
Список використаної літератури
}

Методика навчання іноземних мов і культур: теорія і практика: підручник для студ. класичних, педагогічних i лінгвістичних університетів / Бігич О.Б., Бориско Н.Ф., Борецька Г.Е. та ін. / за загальн. ред. С.Ю.Ніколаєвої. К.: Ленвіт, 2013. 590c

Chilcott Dunkel J. Effective Use of Simulations in the Classroom. Creative Learning Exchange, 1996. 37 p.

Curtain H.A., Pesola C.A. Languages and children - making the match. Reading, MA: Addison-Wesley, 1988. 325p.

Fanous L. Teaching Communicative English Language in Non-Native Contexts using Simulations. URL: http://web.aou. edu.lb/images/stories/lebanon/Research/CALR/7annex/CALR\%207\%20selected\%20proceedings\%203.pdf. (дата звернення: 01.04.2019)

Genzel R.B., Cummings M.G. Culturally speaking: A conversation and culture text for learners of English. New York: Harper and Row, 1986. 251p.

Johannesen R.L. Ethics in Human Communication, 4th ed. Prospect Heights, IL: Waveland Press, 1996. 397p.

Jones K. Simulation in language teaching. The Internet TESL Journal, 2002. UR: http://www.melta.org.my/index.php/11-meltaarticles/173-simulation-in-language-teaching-its-advantages-and-limitations-in-an-esp-context (дата звернення: 01.04.2019).

Sturtridge, G. Using simulation in Teaching English for specific purposes. London, UK: The British Council Press, 1977. 55p.

\section{References}

Bihych, O.B., Borysko, N.F., \& Boretska, H.E (2013). Medodyka navchannia inozemnych mov i kultur: teoriia i praktyka [Methodology of teaching foreign languages and cultures: theory and practice]. Kyiv: Lenvit. [in Ukrainian].

Chilcott Dunkel J. (1996). Effective Use of Simulations in the Classroom. Creative Learning Exchange.

Curtain, H.A., \& Pesola, C.A. (1988). Languages and children - making the match. Reading, MA: Addison-Wesley.

Fanous L. Teaching Communicative English Language in Non-Native Contexts using Simulations. URL http://web.aou.edu.lb/ images/stories/lebanon/Research/CALR/7annex/CALR\%207\%20selected\%20proceedings\%203.pdf. (last accessed: 01.04.2019)

Genzel, R.B., \& Cummings, M.G. (1986). Culturally speaking: A conversation and culture text for learners of English. New York: Harper and Row.

Johannesen, R.L. (1996). Ethics in Human Communication, 4th ed. Prospect Heights, IL: Waveland Press.

Jones K. (2002). Simulation in language teaching. The Internet TESL Journal. UR: http://www.melta.org.my/index.php/11melta-articles/173-simulation-in-language-teaching-its-advantages-and-limitations-in-an-esp-context (last accessed: 01.04.2019)

Sturtridge, G. (1977). Using simulation in Teaching English for specific purposes. London, UK: The British Council Press.

Стаття надійшла до редакції 15.04.2019 р. Стаття прийнята до друку 21.04.2019 р.

\author{
Скриль Ирина \\ старший преподаватель \\ заведующая кафедрой иностранных языков \\ Львовский профессиональный коледж гостиннично-туристического и ресторанного сервиса \\ г.Львов, Украина
}

\section{СИМУЛЯЦИИ В ФОРМИРОВАНИИ АНГЛОЯЗЫЧНОЙ ЛЕКСИЧЕСКОЙ КОМПЕТЕНТНОСТИ В ДИАЛОГИЧЕСКОЙ РЕЧИ БУДУЩИХ СПЕЦИАЛИСТОВ ГОСТИННИЧНО-РЕСТОРАННОГО ДЕЛА}

Аннотация. В статье рассматриваются симуляции в формировании англоязычной лексической компетентности в диалогической речи будущих специалистов гостинично-ресторанного дела. Обусловлено симуляцию как один из интерактивных методов. Проанализирована структура симуляции. Определено симуляцию как способ воспроизведения реальных ситуаций на английском языке в искусственно созданных условиях. Методика симуляции становится первым выбором для преподавателей иностранному языку по профессиональному направлению, потому что этот метод считается основой среды, которая дает учащимся возможность использовать язык творчески и коммуникативно. Интеграция симуляции в языковые классы вовлекает учащихся в непосредственный опыт познания. Эти знания, в свою очередь, ликвидируют разрыв между миром в классе и реальным опытом, с которым сталкиваются студенты.Автор подчеркивает мотивационную ценность симуляции в развитии коммуникативной компетенции.

Ключевые слова: симуляцияж диалогическая речьж лексическая компетентностьж ролевая игра.

\author{
Скріль Ірина Валентинівна \\ старший викладач \\ завідувач кафедри іноземних мов \\ Львівський професійний коледж готельно-туристичного та ресторанного сервісу \\ м.Львів, Україна
}

\section{СИМУЛЯЦІї У ФОРМУВАННІ АНГЛОМОВНОЇ ЛЕКСИЧНОЇ КОМПЕТЕНТНОСТІ У ДІАЛОГІЧНОМУ МОВЛЕННІ МАЙБУТНІХ ФАХІВЦІВ ГОТЕЛЬНО-РЕСТОРАННОӤ СПРАВИ}

Анотація. Мета статті - проаналізувати симуляцію формування англійської лексичної компетентності в діалогічному виступі для майбутніх фахівців готельно-ресторанної справи. Методи дослідження: аналіз та синтез, індукція та дедукція та огляд педагогічних наукових джерел літератури 3 метою з'ясування теоретичних основ та стану розвитку досліджуваної проблеми. У статті розглядаються симуляції у формуванні 
англомовної лексичної компетентності у діалогічному спілкуванні майбутніх фахівців готельно-ресторанної справи. Обумовлено симуляцію як один з інтерактивних методів. Проаналізовано структуру симуляції. Визначено симуляцію як спосіб відтворення реальних ситуацій на англійській мові в штучно створених умовах. Методика симуляції стає першим вибором для викладачів іноземної мови за професійним спрямуванням через те, що цей метод вважається основою середовища, що дає учням можливість використовувати мову творчо та комунікативно. Інтеграція симуляцій у мовні заняття залучає студентів до практичного досвіду знань. Це знання, у свою чергу, перекриває розрив між класом і реальним досвідом, 3 яким стикаються студенти. Найбільш поширеним баченням симуляції $\epsilon$ те, що вони забезпечують спосіб створення багатого комунікативного середовища (подання реальності), де студенти активно стають частиною певної реальної системи і функціонують відповідно до заданих ролей як членів цієї групи. За допомогою симуляції студенти отримають більше шансів практикувати англійську мову граматично і прагматично, тому що робить це в реальному світі. У симуляції студентам дається завдання виконувати або вирішувати завдання разом з необхідною довідковою інформацією і середовищем, в якому це робити. Симуляція надає реалістичну обстановку для більш широкої взаємодії, в якій студенти можуть отримати більше особистої участі. Автор підкреслює мотиваційну цінність симуляції у розвитку комунікативної компетенції.

Ключові слова: симуляція; діалогічне мовлення; лексична компетентність; рольова гра. 